\title{
Potensi Penambahan Aerami (Air Rendaman Abu Jerami) Sebagai Pengawet Alami Untuk Bahan Makanan
}

\author{
Siti Umaira ${ }^{\mathrm{a}, 1, *}$, Agil Dhiemitra Aulia Dewi ${ }^{\mathrm{b}, 2}$, Astari Puruhita Ansokowati ${ }^{\mathrm{b}, 3}$ \\ a, b Program Studi S1 Gizi Fakultas Ilmu Kesehatan Universitas ‘Asyiyah Yogyakarta, J1. Ringroad Barat No.63, DIY \\ 55592, Indonesia \\ ${ }^{1}$ siti.umaira23@gmail.com*; ${ }^{2}$ agildhiemitra@ unisayogya.ac.id; ${ }^{3}$ astaripuruhita@unisayogya.ac.id \\ * penulis korespondensi
}

\begin{abstract}
The implementation of the new rule, the Enforcement of Restrictions on Community Activities (PPKM) is carried out by the government to suppress the positive cases of Covid-19 due to the impact of a very high increase in cases in Indonesia demanding that people limit activities outside the home. Restrictions on community activities outside the home make people have to store and process food properly and reduce the shopping frequency to the market or out of the house just to buy food. Food preservation is one of the techniques used to increase the shelf life of a food. There are many ways used to preserve food either naturally or by using chemicals. One example is the preservation using straw ash soaking water or better known as ki water. The purpose of this article is to analyze the effectiveness of the use of straw ash soaking water as an alternative preservative and as a natural preservative in food. This research uses the library study method by reviewing and analyzing various literature related to this research. Based on the analysis of data obtained that the addition of the concentration of straw ash soaking water into foodstuffs proved to inhibit the growth of microorganisms and effective to preserve food by extending the shelf life of food. This research is expected to be the basis for further research on the effect of adding straw ash soaking water to the shelf life of a foodstuff.
\end{abstract}

Keywords: foodstuffs, natural preservatives, water soaking straw ash

\section{ABSTRAK}

Penerapan aturan baru yaitu Pemberlakuan Pembatasan Kegiatan Masyarakat (PPKM) dilakukan oleh pemerintah untuk menekan angka positif Covid-19 akibat dari dampak kenaikan kasus yang sangat tinggi di Indonesia menuntut masyarakat agar membatasi kegiatan diluar rumah. Adanya pembatasan kegiatan masyarakat diluar rumah membuat masyarakat harus menyimpan dan mengolah makanan dengan benar dan mengurangi frekuensi belanja ke pasar atau keluar rumah sekadar untuk membeli makanan. Pengawetan makanan adalah salah satu teknik yang digunakan untuk meningkatkan daya simpan suatu makanan. Ada banyak cara yang digunakan untuk mengawetkan makanan baik secara alami atau dengan menggunakan bahan kimia. Salah satu contohnya adalah pengawetan menggunakan air rendaman abu jerami atau lebih dikenal dengan air ki. Tujuan dari artikel ini adalah menganalisis efektifitas penggunaan air rendaman abu jerami sebagai pengawet alternatif dan sebagai pengawet alami pada makanan. Penelitian ini menggunakan metode studi pustaka dengan mengkaji dan melakukan analisis berbagai literatur yang berhubungan dengan penelitian ini. Berdasarkan analisis data yang dilakukan diperoleh bahwa penambahan konsentrasi air rendaman abu jerami kedalam bahan makanan terbukti menghambat pertumbuhan mikroorganisme dan efektif untuk mengawetkan makanan dengan memperpanjang daya simpan makanan. Penelitian ini diharapkan dapat menjadi dasar untuk dilakukannya penelitian yang lebih lanjut mengenai pengaruh penambahan air rendaman abu jerami terhadap daya simpan suatu bahan makanan.

Kata Kunci: air rendaman abu jerami, bahan makanan, bahan pengawet alami. 


\section{Pendahuluan}

Coronaviruses (CoV) atau dikenal dengan Covid-19 merupakan virus corona baru yang ditemukan pertama kali di kota Wuhan dan World Health Organization (WHO) telah menetapkan Corona Virus Disease 2019 (COVID-19) sebagai pandemi global pada Rabu, 11 Maret 2020 (Gugus Tugas Covid-19, 2020). Pada tanggal 26 januari 2021 kasus positif Covid-19 di Indonesia bertambah menjadi 13.094 orang dan lonjakan kasus ini membuat total kasus positif Covid-19 di Indonesia menjadi 1.012.350 orang dan merupakan rekor penambahan kasus yang cukup memprihatinkan (Satgas COVID-19, 2021).

Lonjakan kasus Covid-19 menyebabkan pemerintah memberlakukan Perlakuan Pembatasan Kegiatan Masyarakat atau PPKM sesuai dengan aturan Instruksi Mendagri No. 01 Tahun 2021 untuk mengendalikan kasus penyebaran Covid-19. Dampak dari kegiatan PPKM ini membuat masyarakat lebih banyak menghabiskan waktunya dirumah mulai dari work form home, berkomunikasi dan belajar secara online sehingga membuat kita perlu menyetok bahan makanan dan mengetahui cara menyimpan serta mengelola makanan selama masa pandemi ini dan mengurangi pemborosan makanan. Berdasarkan mudahnya terjadi kerusakan maka makanan dapat dikategorikan menjadi 3 golongan, yaitu makanan tidak mudah rusak (non perishable foods), makanan yang agak mudah rusak (semi perishable foods) dan makanan yang mudah rusak (perishable foods) (Muntikah and Razak, 2017).

Kerusakan bahan pangan dalan dilihat dari perubahan fisik meliputi sifat organoleptic seperti warna, bau, tesktur atau bentuk dan perubahan kimiawi meliputi komponen penyusunnya seperti kadar air, karbohidrat, protein, atau lemak sehingga pengelolaan dan penyimpanan makanan menjadi sangat penting untuk menjaga kualitas dan mutu bahan makanan. Secara umum penyebab kerusakan pada mie basah dan tahu adalah mengandung kadar air yang tinggi. Kandungan air pada tahu sekitar 86\% (Cholifah, Hendrarini and Amri, 2017) sedangkan pada mie basah 52\% sehingga daya tahan simpannya relative singkat (Astawan, 2006). Semakin tinggi kadar air suatu pangan, akan semakin besar kemungkinan kerusakannya baik sebagai akibat aktivitas biologis internal (metabolisme) maupun masuknya mikroba perusak.

Pengawetan makanan adalah salah satu teknik yang digunakan untuk meningkatkan daya simpan suatu makanan. Tujuan dilakukannya pengawetan yang paling penting yaitu untuk mencegah terjadinya kerusakan sehingga dapat memperpanjang daya simpan suatu makanan serta mempertahankan mutunya, dan mempermudah proses penanganan, penyimpanan dan pengangkutan (Muntikah and Razak, 2017). Ada banyak cara yang dapat digunakan untuk mengawetkan makanan baik dengan metode alami seperti pengasapan atau secara modern seperti penggunaan bahan kimia atau pengalengan. Namun tidak sedikit juga masik banyak oknum pedagang yang menggunakan bahan kimia berbahaya untuk mengawetkan makanan. Seperti tinjauan lapangan yang dilakukan oleh Badan Pengawasan Obat dan Makanan kota Yogyakarta pada tahun 2019 di Pasar Argosari Wonosari, Kabupaten Gunungkidul ditemukan ada 3 jenis makanan yang mengandung positif formalin yaitu ikan teri, teri nasi dan cumi keri (Ayoyogya, 2019). Selain itu data dari uji formalin terhadap sampel tahu pada tahun 2015 menunjukkan bahwa dari 768 sampel produk tahu yang diambil secara acak dari beberapa kota di Indonesia terdapat 
sekitar 123 produk tahu yang mengandung formalin atau boraks (Wahidin, As'ad, Laksmisari, and Ramadhani, 2019).

Fenomena penggunaan formalin pada makanan ini menunjukkan bahwa masih kurangnya pengetahuan masyarakat mengenai bahan pengawet yang telah diizinkan oleh pemerintah. Penelitian yang dilakukan pada tahun 2017 di kota Semarang menunjukkan bahwa adanya hubungan positif antara pengetahuan pedagang mengenai penggunaan formalin dalam makanan (Aziza, Rahfiludin and Pangestuti, 2017).

Air rendaman abu jerami atau lebih dikenal dengan air ki adalah air saringan hasil endapan abu jerami yang sudah melalui proses pembakaran dan perendaman selama beberapa hari. Air rendaman abu jerami merupakan produk pengembangan bahan pengawet alami yang dapat mengawetkan pangan hal ini terbukti dari penelitian yang dilakukan oleh Yuliana, Widyastuti dan Werdiningsih (2018) bahwa rendaman air abu jerami dapat meningkatkan daya simpan pada mie basah selama 30 jam yang terbuat dari tepung mocaf dengan penambahan konsentrasi air rendaman abu jerami sekitar 5\% (Yuliana, Widyastuti and Werdiningsih, 2018).

Penggunaan bahan pengawet sintetis dan berbahaya yang berlebihan harus diimbangi dengan upaya pengembangan bahan pengawet alami yang aman dengan metode menghambat pertumbuhan bakteri. Tahu yang telah direndam dengan air ki konsentrasi $50 \%$ terbukti dapat menghambat adanya pertumbuhan mikroba dan bakteri E.coli. Penelitian lain mengatakan bahwa konsentrasi pektin yang terdapat didalam jerami sekitar $0.5 \%$ gram terbukti mampu mengawetkan buah strawberi selama 28 hari (Fajar, Maulana and Dasuki, 2015). Selain itu penelitian menggunakan sampel mie tiaw menunjukkan konstrasi air kki yang paling tepat sebagai bahan pengawet alami adalah konsentrasi 2,5\% (Yulia, 2017).

Hasil penelitian ini diharapkan dapat menjadi dasar pengembangan air ki sebagai bahan pengawet karena mampu menghambat pertumbuhan bakteri. Fokus utama dalam literatur review ini adalah untuk mengetahui keefektifan dari penambahan air ki pada berbagai bahan makanan sebagai bahan pengawet alami sehingga dapat dikembangkan menjadi bahan pengawet alami yang tidak membahayakan kesehatan manusia.

\section{Metode Penelitian}

Penelitian ini merupakan literature review dengan melakukan pengkajian dan menganalisis mengenai hasil penelitian yang terkait dengan potensi penambahan air rendaman abu jerami untuk meningkatkan daya simpan bahan makanan melalui pencarian literature yang berkaitan dengan menggunakan database dari berbagai referensi, seperti jurnal penelitian, dan data-data yang berkaitan dengan potensi air rendaman abu jerami sebagai bahan pengawet alternatif.

Tahap awal adalah pencarian artikel jurnal dan ditemukan 24 artikel yang berkaitan. Dari jumlah tersebut hanya sekitar 7 artikel yang Dianggap relevan dan dari jumlah tersebut 6 artikel yang memiliki kriteria penuh. Kriteria inklusi artikel adalah: publikasi dari tahun 2010-2020, full paper, artikel berbahasa Indonesia dan Inggris, dengan kata kunci 'Air Rendaman Abu Jerami, 'Air Ki', dan 'Bahan Pengawet Alami'. 


\section{Hasil dan Pembahasan}

Berdasarkan hasil kajian terhadap penggunaan bahan pengawet alternatif dan alami melalui penambahan konsentrasi air rendaman abu jerami untuk memperpanjang daya simpan bahan makanan, maka didapatkan bahwa penambahan air rendaman abu jerami terbukti dapat memperpanjang daya simpan bahan makanan. Jerami yang digunakan untuk pembuatan air ki atau air rendaman abu jerami mengandung sekitar 32\% selulosa, 24\% hemiselulosa dan mengandung lignin. Tangkai dan batang dari jerami yang keras mengandung lignin, sehingga dapat memberikan struktur keras pada padi. Kandungan lignin yang terdapat didalam jerami dapat mengalami proses pirolisis melalui proses pemanasan dan menghasilkan senyawa antimikroba sehingga dapat berperan dalam meningkatkan daya simpan bahan makanan (Yulia, 2017).

\subsection{Pengaruh Penambahan Air Ki Terhadap Warna Bahan Makanan}

Warna merupakan suatu sifat fisik yang terdapat pada makanan. Mutu pangan terdiri dari beberapa aspek yaitu aspek gizi (kalori, protein, lemak, mineral, vitamin, dan lainlain), aspek selera (indrawi, rasa, menarik, segar), aspek bisnis (standar mutu, kriteria mutu) serta aspek kesehatan (jasmani dan rohani) (Christine F. M., 2016). Warna pada bahan makanan dipengaruhi oleh beberapa faktor seperti aktifitas enzim, pigmen yang terkandung dalam bahan makanan, proses pengolahan, asam-asam organik, dan penambahan zat pewarna buatan (Christine F. M., 2016).

Penelitian mengenai penambahan air rendaman abu jerami atau air ki kedalam bahan makanan dan pengaruhnya terhadap warna bahan makanan disajikan dalam Tabel 3.1. Hasil penelitian yang dilakukan oleh Wulandari et.al (2020) Ditemukan efek yang nyata pada warna tahu dengan penambahan air ki dengan berbagai variasi. Konsentrasi yang paling efektif untuk dijadikan sebagai bahan pengawet alami pada tahu adalah penambahan konsentrasi air ki 5\%, karena pada hari keempat perendaman warna tahu berubah menjadi putih kekuningan sementara konsentrasi 2\%,3\%,4\%, dan 6\% sudah berubah menjadi putih kecoklatan. Sementara penelitian yang dilakukan oleh Wahidin et.al (2019) penambahan konsentrasi air ki semakin tinggi dapat menyebabkan perubahan warna pada tahu sehingga diperlukan konsentrasi yang tepat agar tidak mempengaruhi warna dan kualitas pada tahu.

Hasil penelitian pada penambahan air ki pada mie basah juga memiliki efek yang positif terhadap warna mie basah. Penambahan air ki dan sari kunyit pada mie basah menghasilkan warna kuning kemerahan, akibat penambahan sari kunyit ini warna mie basah yang dihasilkan adalah warna kuning kemerahan yang disebabkan oleh pigmen alami didalam kunyit yaitu kurkuminoid (Yuliana, Widyastuti and Werdiningsih, 2018). Pengujian yang dilakukan dengan melibatkan panelis untuk menilai warna pada mie basah yang diamati menunjukkan bahwa panelis lebih menyukai warna mie basah dengan penambahan konsentrasi air ki 5\% dan sari kunyit 1\% (Serie, Nur'aini and R. Hidaiyanti, 2014). 
Tabel 3.1 Pengaruh Penambahan Air Ki Terhadap Warna

\begin{tabular}{|c|c|c|c|}
\hline $\begin{array}{c}\text { Bahan } \\
\text { Makanan }\end{array}$ & Metode Penelitian & Hasil Penelitian & Referensi \\
\hline Tahu & $\begin{array}{l}\text { Pemberian air ki } \\
\text { konsentrasi } 2 \%, 3 \%, \\
4 \%, 5 \% \text { dan } 6 \% \text { pada } \\
\text { tahu dan dilakukan } \\
\text { perendaman selama } 4 \\
\text { hari }\end{array}$ & $\begin{array}{l}\text { Hasil analisis didapatkan } \\
\text { bahwa penambahan air ki } \\
\text { berpengaruh terhadap warna } \\
\text { tahu. Konsentrasi 5\% larutan } \\
\text { yang efisien dalam } \\
\text { pengawetan tahu }\end{array}$ & $\begin{array}{l}\text { (Wulandari, } \\
\text { Azizah } \\
\text { Choiruddin, } \\
\text { 2020). }\end{array}$ \\
\hline Tahu & $\begin{array}{l}\text { Pemberian air ki } \\
\text { konsentrasi } 0 \%, 40 \% \\
\text { dan } 50 \% \text { pada tahu dan } \\
\text { dilakukan perendaman } \\
\text { selama } 3 \text { hari }\end{array}$ & $\begin{array}{l}\text { Hasil analisis didapatkan } \\
\text { semakin tinggi konsentrasi } \\
\text { air ki yang ditambahkan } \\
\text { dapat menyebabkan } \\
\text { perubahan warna pada tahu }\end{array}$ & $\begin{array}{l}\text { (Wahidin, As'ad, } \\
\text { Laksmisari, and } \\
\text { Ramadhani, } \\
\text { 2019). }\end{array}$ \\
\hline Mie basah & $\begin{array}{l}\text { Pemberian ekstrak abu } \\
\text { jerami konsentrasi } 3 \% \text {, } \\
5 \% \text { dan } 7 \% \text { serta } \\
\text { penambahan sari } \\
\text { kunyit } 1 \% \text { dan } 1,5 \% \\
\text { dan uji hedonik }\end{array}$ & $\begin{array}{l}\text { Hasil analisis didapatkan } \\
\text { bahwa konsentrasi air ki } 5 \% \\
\text { dan air kunyit } 1 \% \text { warnanya } \\
\text { lebih disukai oleh panelis }\end{array}$ & $\begin{array}{l}\text { (Serie, Nur'aini } \\
\text { and R. Hidaiyanti, } \\
\text { 2014). }\end{array}$ \\
\hline Mie basah & $\begin{array}{l}\text { Pemberian air } \quad \text { ki } \\
\text { konsentrasi } 5 \% \text { dan } \\
\text { sari kunyit } 4 \% \text { dan uji } \\
\text { hedonik }\end{array}$ & $\begin{array}{l}\text { Hasil analisis didapatkan } \\
\text { bahwa terjadi perubahan } \\
\text { warna pada mie basah } \\
\text { dengan penambahan air ki } \\
\text { dan sari kunyit. }\end{array}$ & $\begin{array}{l}\text { (Yuliana, } \\
\text { Widyastuti and } \\
\text { Werdiningsih, } \\
\text { 2018). }\end{array}$ \\
\hline $\begin{array}{l}\text { Cumi-Cumi } \\
\text { asap }\end{array}$ & $\begin{array}{l}\text { Pemberian air ki } \\
\text { konsentrasi } 0 \%, 0,5 \% \text {, } \\
\text { dan } 1 \% \text { dan kelompok } \\
\text { lama penyimpanan } \\
\text { terdiri dari } 0 \text { hari, } 5 \\
\text { hari, } 10 \text { hari dan } 15 \\
\text { hari. }\end{array}$ & $\begin{array}{l}\text { Hasil analisis didapatkan } \\
\text { bahwa terjadi perubahan } \\
\text { warna dan warna cumi-cumi } \\
\text { asap yang dihasilkan adalah } \\
\text { kekuningan dan sedikit } \\
\text { cemerlang. }\end{array}$ & $\begin{array}{l}\text { (Dahlia and } \\
\text { Pulungan, 2011). }\end{array}$ \\
\hline
\end{tabular}

Tabel 3 menunjukkan sampel snack cumi-cumi asap dengan penambahan air ki yang terdiri dari tiga konsentrasi yaitu $0 \%, 0,5 \%$ dan $1 \%$ didapatkan nilai rupa warna pada konsentrasi $1 \%$ terendah dan konsentrasi $0 \%$ adalah yang tertinggi. Sehingga penambahan air ki pada snack cumi-cumi asap memiliki efek yang nyata terhadap warna pada sampel.

\subsection{Pengaruh Penambahan Air Ki Terhadap Rasa Bahan Makanan}

Parameter rasa menjadi salah satu aspek penting yang harus diamati, sehingga bahan makanan yang dihasilkan memiliki rasa yang normal, tidak basi, tidak tejadi penurunan mutu dan aman untuk dikonsumsi oleh konsumen. Secara subyektif, citarasa dapat juga diamati dengan uji organoleptik. Berdasarkan hasil penelitian yang dilakukan dengan 
penambahan beberapa konsentrasi air rendaman abu jerami kedalam bahan makanan diperoleh data yang disajikan pada Tabel 3.2.

Tabel 3.2 Pengaruh Penambahan Air Ki Terhadap Rasa

\begin{tabular}{|c|c|c|c|}
\hline $\begin{array}{c}\text { Bahan } \\
\text { Makanan }\end{array}$ & Metode Penelitian & Hasil Penelitian & Referensi \\
\hline Tahu & $\begin{array}{l}\text { Pemberian } \begin{array}{l}\text { air } \\
\text { konsentrasi }\end{array} 2 \%, 3 \%, 4 \% \text {, } \\
5 \% \text { dan } 6 \% \text { pada tahu dan } \\
\text { dilakukan perendaman } \\
\text { selama } 4 \text { hari dan uji } \\
\text { hedonik }\end{array}$ & $\begin{array}{l}\text { Hasil analisis didapatkan } \\
\text { bahwa penelis lebih menyukai } \\
\text { rasa tahu dengan konsentrasi } \\
5 \% \text {. }\end{array}$ & $\begin{array}{l}\text { (Wulandari, } \\
\text { Azizah and } \\
\text { Choiruddin, } \\
\text { 2020). }\end{array}$ \\
\hline Tahu & $\begin{array}{l}\text { Pemberian air ki } \\
\text { konsentrasi } 0 \%, 40 \% \text { dan } \\
50 \% \text { pada tahu dan uji } \\
\text { organoleptik dilakukan } \\
\text { oleh } 40 \text { panelis }\end{array}$ & $\begin{array}{l}\text { Hasil analisis didapatkan } \\
\text { bahwa panelis lebih menyukai } \\
\text { rasa tahu dengan konsentrasi } \\
\text { air ki } 50 \% \text {. }\end{array}$ & $\begin{array}{l}\text { (Wahidin, } \\
\text { As'ad, } \\
\text { Laksmisari, } \\
\text { and } \\
\text { Ramadhani, } \\
\text { 2019). }\end{array}$ \\
\hline Mie basah & $\begin{array}{l}\text { Pemberian ekstrak abu } \\
\text { jerami konsentrasi } 3 \%, 5 \% \\
\text { dan } 7 \% \text { serta penambahan } \\
\text { sari kunyit } 1 \% \text { dan } 1,5 \% \\
\text { dan uji DMRT }\end{array}$ & $\begin{array}{l}\text { Hasil analisis didapatkan } \\
\text { bahwa konsentrasi air ki } 5 \% \\
\text { dan air kunyit } 1 \% \text { berpeluang } \\
\text { diterima oleh konsumen. }\end{array}$ & $\begin{array}{l}\text { (Serie, } \\
\text { Nur'aini and } \\
\text { R. Hidaiyanti, } \\
\text { 2014). }\end{array}$ \\
\hline Mie basah & $\begin{array}{l}\text { Pemberian air } \\
\text { konsentrasi } 5 \% \text { dan } \\
\text { kunyit } 4 \% \text { dan } \\
\text { organoleptic rasa secara } \\
\text { hedonik dan skoring }\end{array}$ & $\begin{array}{l}\text { Hasil analisis didapatkan } \\
\text { bahwa terjadi penurunan rasa } \\
\text { pada mie basah selama } \\
\text { penyimpanan }\end{array}$ & $\begin{array}{l}\text { (Yuliana, } \\
\text { Widyastuti } \\
\text { and } \\
\text { Werdiningsih, } \\
\text { 2018). }\end{array}$ \\
\hline $\begin{array}{l}\text { Cumi- } \\
\text { Cumi } \\
\text { asap }\end{array}$ & $\begin{array}{l}\text { Pemberian air ki } \\
\text { konsentrasi } 0 \%, 0,5 \% \text {, dan } \\
1 \% \text { dan kelompok lama } \\
\text { penyimpanan terdiri dari } 0 \\
\text { hari, } 5 \text { hari, } 10 \text { hari dan } 15 \\
\text { hari. }\end{array}$ & $\begin{array}{l}\text { Hasil analisis didapatkan } \\
\text { bahwa semakin } r \text { tinggi } \\
\text { konsentrasi abu merang } \\
\text { semakin menurun rasa snack } \\
\text { cumi-cumi asap }\end{array}$ & $\begin{array}{l}\text { (Dahlia and } \\
\text { Pulungan, } \\
\text { 2011). }\end{array}$ \\
\hline
\end{tabular}

Secara keseluruhan penambahan air rendaman abu jerami terhadap bahan makanan berkorelasi positif terhadap rasa pada sampel tahu dan mie basah dengan uji DMRT. Penelitian yang dilakukan oleh Wulandari et.al (2020) pada sampel tahu ditemukan bahwa sampel tahu yang paling disukai oleh panelis adalah tahu dengan konsentrasi air ki 5\%. Dan pada mie basah yang dilakukan penelitian oleh Serie et.al (2014) mie basah yang berpeluang paling besar untuk disukai oleh konsumen pasar adalah mie basah dengan konsentrasi air ki 5\% dan sari kunyit $1 \%$. 


\subsection{Pengaruh Penambahan Air Ki Terhadap Aroma Bahan Makanan}

Aroma adalah bau yang ditangkap oleh indera penciuman dari suatu bahan makanan. Aroma pada bahan makanan tentu menjadi daya tarik bahan makanan tersebut sehingga memainkan peran yang cukup penting dalam sebuah industri makanan (Tarwendah, 2017). Berdasarkan hasil penelitian yang disajikan pada Tabel 3 yang melibatkan beberapa panelis pada sampel mie basah didapatkan bahwa Penambahan air ki memiliki efek yang nyata pada aroma mie basah, hal ini terbukti bahwa mie basah dengan perlakuan menghasilkan aroma yang berbeda dengan mie basah tanpa perlakuan (Serie, Nur'aini and R. Hidaiyanti, 2014).

Hal ini berbeda dengan penelitian yang sudah dilakukan oleh Yuliana et.al (2018) bahwa semakin lama penyimpanan pada mie basah dengan perlakuan membuat penurunan pada aroma mie basah. Sedangkan pada sampel tahu dengan penambahan air ki selama perendaman didapatkan bahwa pada konsentrasi 5\% dari $100 \mathrm{ml}$ aquadest pada hari pertama perendaman bau yang dihasilkan masih dikategorikan normal (Wulandari, Azizah and Choiruddin, 2020).

Tabel 3.3 Pengaruh Penambahan Air Ki Terhadap Aroma

\begin{tabular}{|c|c|c|c|}
\hline $\begin{array}{c}\text { Bahan } \\
\text { Makanan }\end{array}$ & Metode Penelitian & Hasil Penelitian & Referensi \\
\hline Tahu & $\begin{array}{l}\text { Pemberian air ki konsentrasi } \\
2 \%, 3 \%, 4 \%, 5 \% \text { dan } 6 \% \\
\text { pada tahu dan dilakukan } \\
\text { perendaman selama } 4 \text { hari }\end{array}$ & $\begin{array}{l}\text { Hasil analisis didapatkan } \\
\text { bahwa konsentrasi } 5 \% \text { lebih } \\
\text { efektif. }\end{array}$ & $\begin{array}{l}\text { (Wulandari, } \\
\text { Azizah and } \\
\text { Choiruddin, } \\
\text { 2020). }\end{array}$ \\
\hline Tahu & $\begin{array}{l}\text { Pemberian air ki konsentrasi } \\
0 \%, 40 \% \text { dan } 50 \% \text { pada tahu } \\
\text { dan dilakukan perendaman } \\
\text { selama } 3 \text { hari }\end{array}$ & $\begin{array}{l}\text { Hasil analisis didapatkan } \\
\text { bahwa konsentrasi } 40 \% \\
\text { lebih efektif. }\end{array}$ & $\begin{array}{l}\text { (Wahidin, As'ad, } \\
\text { Laksmisari, and } \\
\text { Ramadhani, } \\
\text { 2019). }\end{array}$ \\
\hline $\begin{array}{l}\text { Mie } \\
\text { basah }\end{array}$ & $\begin{array}{l}\text { Pemberian ekstrak abu jerami } \\
\text { konsentrasi } 3 \%, 5 \% \text { dan } 7 \% \\
\text { serta penambahan sari kunyit } \\
1 \% \text { dan } 1,5 \% \text { dan uji DMRT }\end{array}$ & $\begin{array}{l}\text { Hasil analisis didapatkan } \\
\text { bahwa penambahan air ki } \\
\text { memiliki efek yang positif } \\
\text { terhadap bau mie basah. }\end{array}$ & $\begin{array}{l}\text { (Serie, Nur'aini } \\
\text { and } \quad \text { R. } \\
\text { Hidaiyanti, } \\
\text { 2014). }\end{array}$ \\
\hline $\begin{array}{l}\text { Mie } \\
\text { basah }\end{array}$ & $\begin{array}{l}\text { Pemberian air ki konsentrasi } \\
5 \% \text { dan sari kunyit } 4 \% \text { dan } \\
\text { uji organoleptik rasa secara } \\
\text { skoring dan hedonik }\end{array}$ & $\begin{array}{l}\text { Hasil analisis didapatkan } \\
\text { bahwa semakin lama } \\
\text { penyimpanan menyebabkan } \\
\text { penurunan aroma mie basah. }\end{array}$ & $\begin{array}{l}\text { (Yuliana, } \\
\text { Widyastuti and } \\
\text { Werdiningsih, } \\
\text { 2018). }\end{array}$ \\
\hline Snack & Pemberian air ki konsentrasi & Rata-rata nilai bau dapat & (Dahlia and \\
\hline $\begin{array}{l}\text { Cumi- } \\
\text { cumi } \\
\text { asap }\end{array}$ & $\begin{array}{l}0 \%, 0,5 \% \text {, dan } 1 \% \text { dan } \\
\text { kelompok lama penyimpanan } \\
\text { terdiri dari } 0 \text { hari, } 5 \text { hari, } 10 \\
\text { hari dan } 15 \text { hari. }\end{array}$ & $\begin{array}{l}\text { dikategorikan sebagai } \\
\text { kurang harum dan tanpa bau } \\
\text { mengganggu. }\end{array}$ & Pulungan, 2011). \\
\hline
\end{tabular}

Sedangkan pada sampel snack cumi-cumi asap penambahan air ki pada sampel yang terlalu tinggi juga akan mempengaruhi aroma atau bau pada snack cumi-cumi asap. Dan 
hasil menunjukkan bahwa aroma rata-rata pada snack cumi-cumi asap yaitu kurang harum sehingga dapat disimpulkan bahwa penambahan air ki memiliki efek yang nyata terhadap bau snack cumi-cumi asap. (Dahlia and Pulungan, 2011).

\subsection{Pengaruh Penambahan Air Rendaman Abu Jerami Terhadap Tekstur Bahan Makanan}

Atribut sensori yang selanjutnya diperhatikan adalah tekstur. Tekstur mencangkup dari kekentalan atau viskositas suatu bahan makanan merupakan suatu respon dari tactile sense terhadap bentuk rangsangan fisik ketika melakukan kontak dengan rongga mulut terhadap suatu makanan (Tarwendah, 2017). Pengamatan dari segi tekstur bahan makanan yang sudah diberi perlakuan penambahan konsentrasi air ki disajikan pada Tabel 3.4. Berdasarkan hasil data pada Tabel 3.4 dapat diintreprestasikan bahwa tekstur tahu dengan Penambahan air ki 5\% tidak Berkorelasi positif dengan tekstur tahu karena tahu yang dihasilkan selama perendaman lunak dengan bau yang asam. Sehingga penambahan air ki dapat mempengaruhi tekstur tahu. Sementara penambahan air ki sekitar 50\% memberikan efek yang positif pada tekstur tahu karena selama 3 hari perendaman tekstur tahu yang dihasilkan normal.

Tabel 3.4 Pengaruh Penambahan Air Ki Terhadap Tekstur

\begin{tabular}{|c|c|c|c|}
\hline $\begin{array}{c}\text { Bahan } \\
\text { Makanan }\end{array}$ & Metode Penelitian & Hasil Penelitian & Referensi \\
\hline Tahu & $\begin{array}{l}\text { Pemberian air ki konsentrasi } \\
2 \%, 3 \%, 4 \%, 5 \% \text { dan } 6 \% \\
\text { pada tahu dan dilakukan } \\
\text { perendaman selama } 4 \text { hari }\end{array}$ & $\begin{array}{l}\text { Hasil analisis didapatkan } \\
\text { bahwa tidak memiliki } \\
\text { efek yang positif terhadap } \\
\text { tekstur tahu. }\end{array}$ & $\begin{array}{l}\text { (Wulandari, } \\
\text { Azizah and } \\
\text { Choiruddin, } \\
\text { 2020). }\end{array}$ \\
\hline Tahu & $\begin{array}{l}\text { Pemberian air ki konsentrasi } \\
0 \%, 40 \% \text { dan } 50 \% \text { pada tahu } \\
\text { dan dilakukan perendaman } \\
\text { selama } 3 \text { hari }\end{array}$ & $\begin{array}{l}\text { Hasil analisis didapatkan } \\
\text { bahwa konsentrasi } 50 \% \\
\text { lebih efektif. }\end{array}$ & $\begin{array}{l}\text { (Wahidin, As'ad, } \\
\text { Laksmisari, and } \\
\text { Ramadhani, } \\
\text { 2019). }\end{array}$ \\
\hline $\begin{array}{l}\text { Mie } \\
\text { basah }\end{array}$ & $\begin{array}{l}\text { Pemberian ekstrak abu jerami } \\
\text { konsentrasi } 3 \%, 5 \% \text { dan } 7 \% \\
\text { serta penambahan sari kunyit } \\
1 \% \text { dan } 1,5 \% \text { dan uji DMRT }\end{array}$ & $\begin{array}{l}\text { Hasil analisis didapatkan } \\
\text { bahwa memiliki efek yang } \\
\text { positif terhadap } \\
\text { kekenyalan mie basah. }\end{array}$ & $\begin{array}{l}\text { (Serie, Nur'aini } \\
\text { and } \\
\text { Hidaiyanti, } \\
\text { 2014). }\end{array}$ \\
\hline Snack & Pemberian air ki konsentrasi & Hasil analisis didapatkan & (Dahlia and \\
\hline $\begin{array}{l}\text { Cumi- } \\
\text { cumi } \\
\text { asap }\end{array}$ & $\begin{array}{l}0 \%, 0,5 \%, \text { dan } 1 \% \text { dan } \\
\text { kelompok lama penyimpanan } \\
\text { terdiri dari } 0 \text { hari, } 5 \text { hari, } 10 \\
\text { hari dan } 15 \text { hari. }\end{array}$ & $\begin{array}{l}\text { bahwa penambahan air ki } \\
\text { memiliki efek yang positif } \\
\text { terhadap tekstur. }\end{array}$ & Pulungan, 2011). \\
\hline
\end{tabular}

Sedangkan secara keseluruhan pada sampel mie basah dan snack cumi-cumi asap dengan penambahan air ki mempengaruhi tekstur pada sampel. Mie basah dengan konsentrasi air ki 5\% dan sari kunyit $1 \%$ adalah yang paling efektif dan berpeluang paling diterima oleh konsumen karena secara keseluruhan hasil nilai rata-rata mie dengan 
konsentrasi air ki 5\% dan sari kunyit 1\% adalah yang tertinggi dan disukai oleh panelis (Serie, Nur'aini and R. Hidaiyanti, 2014). Pada sampel snack cumi-cumi asap dengan penambahan air ki didapatkan bahwa rata-rata tekstur pada snack cumi-cumi asap meningkat seiring dengan penambahan konsentrasi air ki yang tinggi (Dahlia and Pulungan, 2011).

\subsection{Pengaruh Penambahan Air Rendaman Abu Jerami Terhadap Kandungan Mikroba}

Efektivitas penambahan variasi konsentrasi air ki kedalam tahu untuk melihat konsentrasi mana yang lebih tepat untuk digunakan sebagai bahan pengawet alami, Didapatkan bahwa hasil penelitian yang menujukkan konsentrasi air ki 5\% dan 50\% terbukti efektif dijadikan sebagai bahan pengawet alami untuk tahu sehingga dapat meningkatkan daya simpan tahu. Sehingga disarankan untuk menggunakan campuran air ki dengan konsentrasi 5\% atau 50\% untuk mengawetkan tahu.

Namun perlu juga melihat dari segi rasa, tekstur, aroma,perubahan warna pada tahu dan cemaran mikrobanya sehingga dapat menggunakan konsentrasi yang sesuai dengan efektifitasnya. Pada Tabel 3.5 disajikan hasil uji mikroba pada tahu yang sudah direndam dengan air ki, menunjukkan bahwa tahu dengan konsentrasi air ki 50\% memiliki efek yang positif untuk dijadikan sebagai pengawet pada tahu karena dapat menghambat adanya pertumbuhan mikroba dan bakteri E.coli. Tahu dengan penambahan konsentrasi air ki 5\% belum dilakukan uji mikroba sehingga perlu dilakukan penelitian yang lebih lanjut lagi mengenai hasil uji mikroba pada tahu dengan konsentrasi air ki 5\%.

Tabel 3.5 Hasil Uji Mikrobiologi TPC dan E.coli pada Tahu

\begin{tabular}{|c|c|c|c|c|}
\hline \multirow{2}{*}{ Perlakuan } & \multirow{2}{*}{$\begin{array}{c}\text { Hari Perendaman } \\
\text { Ke: }\end{array}$} & \multicolumn{2}{|c|}{ Jumlah Koloni (cfu mL) } & \multirow{2}{*}{ Referensi } \\
\hline & & TPC & E. coli & \\
\hline \multirow{5}{*}{ Kontrol } & 1 & $1.2 \times 10^{7}$ & $5.2 \times 10^{5}$ & \\
\hline & 2 & $1.1 \times 10^{7}$ & $6.3 \times 10^{5}$ & \\
\hline & 3 & $1.4 \times 10^{7}$ & $7.1 \times 10^{5}$ & \\
\hline & 4 & $1.5 \times 10^{7}$ & $7.8 \times 10^{5}$ & \\
\hline & 5 & $2.1 \times 10^{7}$ & $8.7 \times 10^{5}$ & ( Wahidin, As'ad, \\
\hline \multirow{3}{*}{$40 \%$} & 1 & $1.4 \times 10^{7}$ & $5.2 \times 10^{5}$ & Laksmisari, and \\
\hline & 2 & $4.3 \times 10^{6}$ & $6.3 \times 10^{5}$ & Ramadhani, 2019). \\
\hline & 3 & $4.1 \times 10^{6}$ & $7.1 \times 10^{5}$ & \\
\hline \multirow{7}{*}{$50 \%$} & 4 & $3.7 \times 10^{6}$ & $7.8 \times 10^{5}$ & \\
\hline & 5 & $2.8 \times 10^{6}$ & $8.7 \times 10^{5}$ & \\
\hline & 1 & $9.8 \times 10^{6}$ & $3.8 \times 10^{5}$ & \\
\hline & 2 & $1.3 \times 10^{6}$ & Kontaminasi & \\
\hline & 3 & $8.7 \times 10^{5}$ & $1.8 \times 10^{5}$ & \\
\hline & 4 & $7.3 \times 10^{5}$ & $<1.3 \times 10^{5}$ & \\
\hline & 5 & $5.5 \times 10^{5}$ & $<1.2 \times 10^{5}$ & \\
\hline
\end{tabular}


Hal ini juga didukung dengan penelitian yang dilakukan pada sampel mie tiaw didapatkan bahwa penambahan konsentrasi air ki sekitar 2,5\% terbukti efektif dapat mengawetkan mie tiaw ditunjukkan dengan uji angka kuman yang disajikan pada Tabel 3.6. Didapatkan bahwa semakin besar konsentrasi air ki angka kuman pada mie tiaw semakin kecil yang artinya semakin tinggi daya simpannya (Yulia, 2017).

Tabel 3.6 Hasil Penelitian Angka Kuman Pada Mie Tiaw

\begin{tabular}{cccccccc}
\hline \multirow{2}{*}{ No. } & Pengulangan & \multicolumn{6}{c}{ Angka Kuman $\left(\times 10^{6}\right) \mathrm{kol} / \mathrm{gram}$} \\
\cline { 3 - 7 } & & Kontrol & $0,5 \%$ & $1 \%$ & $1,5 \%$ & $2 \%$ & $2,5 \%$ \\
\hline 1 & I & 1,10 & 0,920 & 0,888 & 0,678 & 0,545 & 0,418 \\
2 & II & 1,12 & 0,976 & 0,890 & 0,588 & 0,405 & 0,412 \\
3 & III & 1,01 & 0,736 & 0,879 & 0,666 & 0,406 & 0,410 \\
4 & IV & 1,10 & 1,024 & 0,678 & 0,516 & 0,500 & 0,410 \\
5 & V & 1,14 & 1,040 & 0,768 & 0,617 & 0,415 & 0,412 \\
\hline & Jumlah & 5,47 & 4,696 & 4,103 & 3,065 & 2,271 & 2,062 \\
\hline & Rata-Rata & 1,09 & 0,939 & 0,939 & 0,613 & 0,454 & 0,412 \\
\hline
\end{tabular}

Sehingga pengawetan menggunakan air rendaman abu jerami merupakan cara tradisional dengan memanfaatkan rempah-rempah atau tanaman yang memiliki kandungan antimikroba, jerami sendiri memiliki kandungan lignin sehingga adanya kandungan ini dapat berperan untuk menghambat terjadinya kerusakan pada bahan makanan akibat tumbuhnya mikroorganisme (Wijaya, Mulyono and Afandi, 2012). Selain itu adanya kandungan antimikroba lain seperti kandungan kalium natrium yang berperan sebagai zat antimikroba yang dapat menghambat adanya pembusukan juga berperan sebagai bahan pengawet (Desrosier, 2008).

Tabel 3.7 Hasil Pengamatan Total Kapang Mie Basah Selama Penyimpanan Suhu Ruang

\begin{tabular}{cc}
\hline Lama Penyimpanan (jam) & Kapang $(\mathrm{CFU} / \mathrm{g})$ \\
\hline 0 & $<1,0 \times 10^{2}$ \\
6 & $<1,0 \times 10^{2}$ \\
12 & $<1,0 \times 10^{2}$ \\
18 & $<1,0 \times 10^{2}$ \\
24 & $<1,0 \times 10^{2}$ \\
30 & $<1,0 \times 10^{2}$ \\
36 & $<1,0 \times 10^{2}$ \\
\hline
\end{tabular}

Penambahan rempah-rempah seperti kunyit, jahe, dan bawang putih juga dapat dikenal sebagai pengawetan tradisional oleh kalangan masyarakat Indonesia. Penambahan air ki dan sari kunyi pada mie basah yang terbuat dari tepung mocaf terbukti dapat meningkatkan daya simpan mie basah dalam waktu sekitar 30 jam (Yuliana, Widyastuti and Werdiningsih, 2018). Hal ini juga sejalan dengan penelitian penambahan air ki dan sari kunyit kedalam mie basah yang mampu menahan pertumbuhan kapang karena jumlah kapang selama penyimpanan 0-36 jam tidak melewati batas SNI yang ditunjukkan dari 
hasil total kapang yang rendah yaitu $<1.0 \times 10^{2} \mathrm{CFU} /$ gram yang disajikan pada Tabel 3.7 (Yuliana, Widyastuti and Werdiningsih, 2018). Adanya penambahan sari kunyit yang mengandung senyawa kurkumin yaitu senyawa antimikroba sehingga dapat dijadikan juga dijadikan sebagai bahan pengawet alami.

Proses pengasapan dan penambahan air ki pada snack cumi-cumi asap juga dapat meningkatkan daya simpan makanan tersebut. Selama proses pengasapan akan terbentuk senyawa fenol yaitu suatu senyawa antimikroba yang dapat menghambat dan membunuh mikroorganisme sehingga meningkatkan daya simpan. Selain itu proses pengasapan juga mengurangi kadar air pada snack cumi-cumi asap. Jika suatu bahan makanan memiliki kandungan air yang tinggi akan mempengaruhi perubahan kimia sehingga menentukan kandungan mikroba pada suatu produk pangan (Herawati, 2008).

\section{Kesimpulan}

Berdasarkan hasil literature review ini diketahui bahwa penambahan air ki pada tahu, mie basah dan cumi-cumi asap terbukti dapat dijadikan sebagai bahan pengawet alternatif pada bahan makanan karena dapat meningkatkan daya tahan makanan dan menghambat pertumbuhan bakteri karena kandungan lignin dan kalium natrium yang terdapat didalam jerami.

Masih kurangnya penelitian lebih lanjut mengenai penambahan air rendaman abu jerami sebagai bahan pengawet pada bahan makanan, sehingga diharapkan penelitian ini dapat dijadikan sebagai dasar untuk dilakukannya penelitian yang lebih lanjut mengenai pengaruh penambahan air rendaman abu jerami terhadap daya simpan suatu bahan makanan juga pengaruh terhadap kandungan gizi bahan makanan tersebut.

\section{Ucapan Terima Kasih}

Dalam penulisan penelitian ini penulis ingin mengucapkan terima kasih kepada ibu Agil Dhiemitra Aulia Dewi, S.Gz., M.PH. dan ibu Astari Puruhita Ansokowati, S.Gz., MPH. sebagai dosen pembimbing yang telah membantu memberikan masukan dan dukungan dalam penulisan artikel penelitian ini. Ucapan terima kasih juga saya ucapkan kepada orang tua saya atas doa dan dukungannya sehingga dapat menyelesaikan penulisan artikel penelitian ini dengan lancar dan tepat waktu.

\section{Pustaka}

Astawan, M. (2006) Membuat Mie dan Bihun. Jakarta: Penebar Swadaya.

Ayoyogya (2019) BPOM DIY Ada 3 Jenis Makanan Berformalin di Pasar Argosari. Available at: https://ayoyogya.com/read/2019/12/09/38036/bbpom-diy-ada-3-jenismakanan-berformalin-di-pasar-argosari.

Aziza, M. U., Rahfiludin, M. zen and Pangestuti, D. R. (2017) 'Perbedaan Kadar Formalin Pada Tahu Putih Di Tingkat Produsen Dan Pedagang Kota Semarang Tahun 2016', 5. Available at: https://media.neliti.com/media/publications/106615-ID-perbedaankadar-formalin-pada-tahu-putih.pdf.

Cholifah, N., Hendrarini, L. and Amri, C. (2017) 'Pemanfaatan Bawang Putih dan Daun 
Pandan sebagai Pengawet Alami Tahu Ditinjau dari Masa Simpan dan Tingkat Kesukaan', Sanitasi: Jurnal Kesehatan Lingkungan, 9(1), p. 10. doi: 10.29238/sanitasi.v9i1.35.

Christine F. M. (2016) Pengawasan Mutu Dan Keamanan Pangan, Journal of Physics A: Mathematical and Theoretical. UNSRAT PRESS Manado. doi: 10.1088/17518113/44/8/085201.

Dahlia and Pulungan, A. R. (2011) 'Penggunaan Abu Merang Padi (Oryza Sativa) Untuk Pengolahan Snack Cumi-Cumi (Loligo sp) Asap Yang Disimpan Secara Vakum', 1, pp. 12-20.

Desrosier, N. W. (2008) ‘Teknologi Pengawetan Pangan'. UI Press.

Fajar, M., Maulana, I. T. and Dasuki, U. A. (2015) 'Isolasi Pektin dari Jerami Padi (Oryza Sativa L.) sebagai Bahan Dasar Pembuatan Edible Film untuk Pelapisan Buah', Prosiding Penelitian SpeSIA Unisba, pp. 199-204.

Gugus Tugas Covid-19 (2020) Protokol Percepatan Penanganan Pandemi Covid-19 (Corona Virus Disease 2019). Available at: https://covid19.go.id/storage/app/media/Protokol/Protokol Percepatan Penanganan Pandemi Corona Virus Disease 2019.pdf.

Herawati, H. (2008) 'Penentuan umur simpan pada produk pangan', Jurnal Litbang Pertanian, 27(4), pp. 124-130.

Muntikah and Razak, M. (2017) Ilmu Teknologi Pangan, Kementerian Kesehatan RI. Indonesia.

Satgas COVID-19 (2021) 'Pasien Sembuh COVID-19 Terus Bertambah', 26 Januari 2021. Available at: https://covid19.go.id/.

Serie, E. T., Nur'aini, H. and R. Hidaiyanti (2014) 'Pengaruh Penambahan Ekstrak Abu Jerami Dan Ekstrak Kunyit Terhadap Elastisitas Dan Mutu Organoleptik Mie Basah', Agritepa, I(1), pp. 52-62.

Tarwendah, I. P. (2017) 'Studi Komparasi Atribut Sensoris Dan Kesadaran Merek Produk Pangan', Jurnal Pangan dan Agroindustri, 5(2), pp. 66-73.

Wahidin, S. et al. (2013) Aplikasi Pemanfaatan Air KI (Air Rendaman Abu Jerami) Sebagai Pengawet Alternatif Pada Tahu, Laporan Akhir Program Kreatifitas Mahasiswa.

Wijaya, C. H., Mulyono, N. and Afandi, F. A. (2012) Bahan Tambahan Pangan Pengawet, IPB Press, Bogor.

Wulandari, M. K., Azizah, S. R. and Choiruddin, A. (2020) 'Potensi " A erami " ( Air Rendaman Jerami ) Sebagai Alternatif Bahan Pengawet Alami Dalam Dunia Industri Tahu di Era Covid-19', (September), pp. 436-440.

Yulia, Y. (2017) 'Efektivitas Pemanfaatan Sampah Merang Padi (Oryza sativa\} Sebagai Pengawet Mie Tiaw Basah', Jurnal Vokasi Kesehatan, 3(2), p. 103. doi: 10.30602/jvk.v3i2.106.

Yuliana, H., Widyastuti, S. and Werdiningsih, W. (2018) 'Perubahan Mutu Mikrobiologi, Kimia, Fisik Dan Organoleptik Mie Basah Tersubstitusi Mocaf Dengan Penambahan Air Ki Dan Sari Kunyit Selama Penyimpanan', pp. 1-19. 